\title{
Field Diagnosis of Citrus Tristeza Virus ${ }^{1}$
}

\section{Stephen H. Futch and Ronald H. Brlansky ${ }^{2}$}

Citrus tristeza virus (CTV) is one of the most important pathogens affecting citrus worldwide. Tristeza was first reported in Florida in the 1950s. By the 1980s, it produced serious losses due to tree decline and death on sour orange and Citrus macrophylla rootstocks. Tree decline continues to be a problem today in groves that still have sour orange rootstock trees remaining. Due to CTV, few if any nursery trees are being propagated in Florida on sour orange, bittersweet or Citrus macrophylla rootstock.

Citrus tristeza virus strains or isolates may vary from mild to severe, causing little damage to severe decline, especially on trees grafted on sour orange rootstock. In cases of infection with mild isolates in trees grown on susceptible rootstocks, trees may be reduced in size, vigor, and fruit yields. Trees with a severe strain may quickly decline and die, with the first symptoms being leaf wilt (Figure 1) and ultimate tree death in several weeks. Additionally, other strains may cause stem-pitting in limes, grapefruit, and sweet orange. Fortunately, stem pitting strains are not currently a problem in Florida.

When trees are propagated on susceptible rootstocks and are infected with CTV decline strains, typical symptoms include: decline, wilting, dieback,

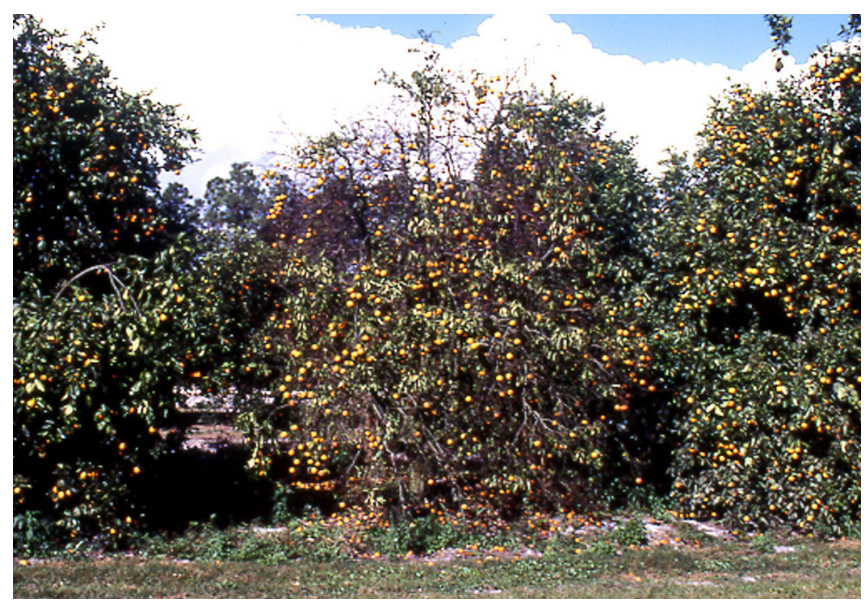

Figure 1. Citrus tree declining due to citrus tristeza virus.

"quick decline," leaf chlorosis and curling, heavy fruit set, honeycombing, bud union staining, scion overgrowth, thickened bark at bud union, starch depletion in roots, and loss of feeder roots. Tree decline results from the necrosis and death (blockage) of the conductive tissue (phloem) at the bud union, whereby sugars produced in the leaves by photosynthesis are effectively blocked from being transported to the roots. Without the transport of sugars and starches to the feeder roots, the roots use up stored starch and begin to decline, leading to the ultimate death of the tree. Decline-inducing strains of the virus may be present in trees on resistant

1. This document is HS996, one of a series of the Horticultural Sciences Department, Florida Cooperative Extension Service, Institute of Food and Agricultural Sciences, University of Florida. Published February 2005. This research was supported by the Florida Agricultural Experiment Station, and approved for publication as Journal Series No. T-00664. Visit the EDIS Web site at http://edis.ifas.ufl.edu.

2. S.H. Futch, extension agent IV, Horticultural Sciences Department, and R.H. Brlansky, professor, Plant Pathology Department, Citrus REC, Lake Alfred, Florida; Cooperative Extension Service, Institute of Food and Agricultural Sciences, University of Florida, Gainesville, 32611.

The Institute of Food and Agricultural Sciences (IFAS) is an Equal Opportunity Institution authorized to provide research, educational information and other services only to individuals and institutions that function with non-discrimination with respect to race, creed, color, religion, age, disability, sex, sexual orientation, marital status, national origin, political opinions or affiliations. U.S. Department of Agriculture, Cooperative Extension Service, University of Florida, IFAS, Florida A. \& M. University Cooperative Extension Program, and Boards of County Commissioners Cooperating. Larry Arrington, Dean 
rootstocks and may provide a reservoir of virus that aphids can spread to susceptible rootstocks.

CTV is transmitted by several aphid species with the most effective being the brown citrus aphid (Toxoptera citricida), which was introduced to Florida in the 1990s. Due to the aphid introduction, CTV rate of spread has increased dramatically within Florida. Additionally, growers have aided in the spread of the virus with the propagation of trees using infected budwood.

Sour orange rootstock, which was frequently and successfully used, is no longer used in Florida due to its susceptibility to CTV. The virus continues to spread and reduce the use of sour orange as a rootstock worldwide. Sour orange has many horticultural advantages, i.e., blight tolerance, adaptation to many soil conditions, tolerance to cold and foot rot, as well as producing fruit of good quality and high yields. Bittersweet sour orange has many of the same horticultural traits as sour orange, including susceptibility to CTV.

Rootstocks that offer resistance to tristeza decline include the citranges (C-35, Carrizo, Troyer), citrumelos (Swingle), mandarins (Cleopatra, Sun Chu Sha, Sunki), mandarin hybrids (Rangpur), lemons (Volkamer, rough), Poncirus trifoliata, Smooth Flat Seville, Kinkoji and Gou Tou.

Steps to determine if a tree on a susceptible rootstock is declining from CTV include:

1. If possible, determine the rootstock, as rootstocks other than sour orange and bittersweet are not affected by CTV. While resistant rootstocks may have the virus, they do not express symptoms like susceptible sour orange and bittersweet rootstocks.

2. Observe the tree condition. CTV-affected trees exhibit an overall decline with the absence of vegetative shoots on the large scaffold branches or limbs near the trunk of the tree. Vegetative shoots can be a sign that a tree is declining due to blight.

3. Examine the tree trunk for any damage that may be limiting the tree growth or health. In many cases, foot rot lesions on the tree trunk will also cause tree decline.

4. Locate the bud union on the tree trunk.

5. Remove a patch of bark from across the bud union.

6. Examine the bark patch below the bud union for numerous small pinholes or honeycombing (Figure 2) areas in the inner face of the bark or a brown discoloration at the bud union which corresponds to the sour orange rootstock portion of the bark sample just below the bud union. These symptoms are not always present on infected trees depending on the virus severity and time of infection.

7. Conduct a syringe water injection test for citrus blight. Occasionally, some old trees on sour orange rootstock have been found to be affected with blight and the inability to inject water will indicate that the tree has xylem blockage that is associated with blight.

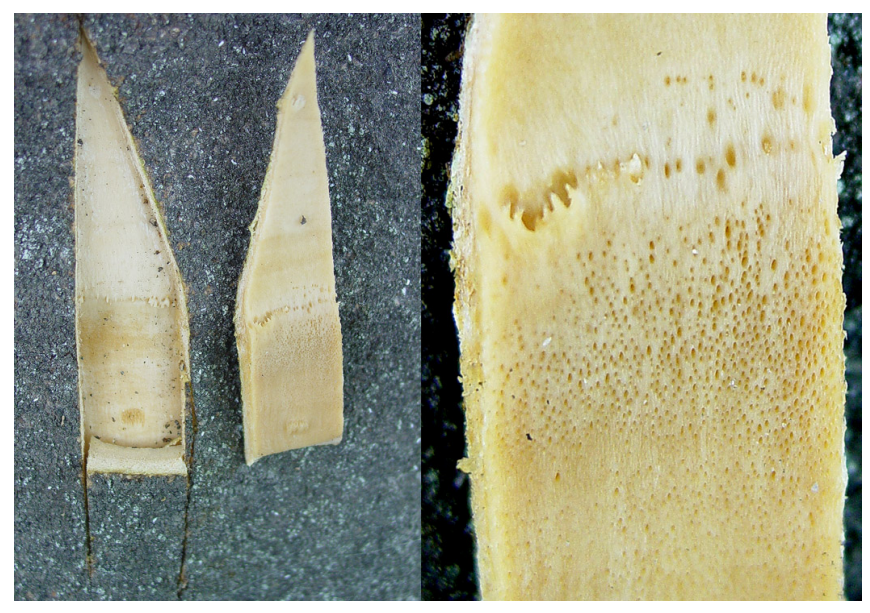

Figure 2. Honeycombing.

In addition to the above field diagnoses, an enzyme-linked immunosorbant assay (ELISA) or immune tissue blot test can be done in a laboratory to detect the presence of mild or severe decline strains of CTV in the plant tissue. 